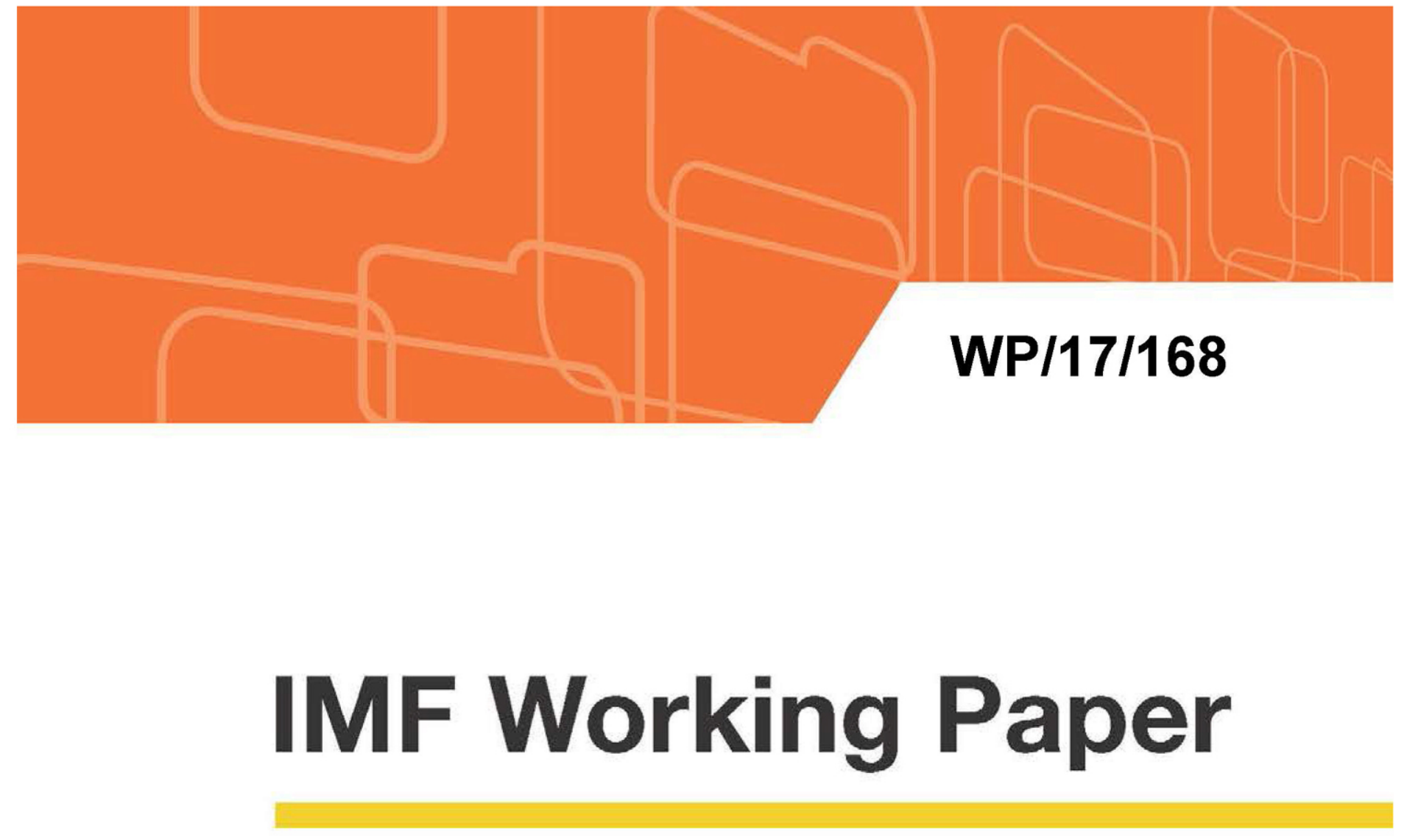

\title{
Efficiency-Adjusted Public Capital, Capital Grants, and Growth
}

by Ernesto Crivelli

IMF Working Papers describe research in progress by the author(s) and are published to elicit comments and to encourage debate. The views expressed in IMF Working Papers are those of the author(s) and do not necessarily represent the views of the IMF, its Executive Board, or IMF management. 


\title{
WP/17/168
}

\section{IMF Working Paper}

\section{Efficiency-Adjusted Public Capital, Capital Grants, and Growth}

\author{
by Ernesto Crivelli
}

IMF Working Papers describe research in progress by the author(s) and are published to elicit comments and to encourage debate. The views expressed in IMF Working Papers are those of the author(s) and do not necessarily represent the views of the IMF, its Executive Board, or IMF management.

$$
\text { I N T E R N A T I O N A L M O N E T A R Y F U N D }
$$




\title{
IMF Working Paper
}

European Department

\section{Efficiency-Adjusted Public Capital, Capital Grants, and Growth ${ }^{1}$ \\ Prepared by Ernesto Crivelli}

Authorized for distribution by Reza Baqir

July, 2017

\section{IMF Working Papers describe research in progress by the author(s) and are published to elicit comments and to encourage debate. The views expressed in IMF Working Papers are those of the author(s) and do not necessarily represent the views of the IMF, its Executive Board, or IMF management.}

\begin{abstract}
Recent literature has explored the relationship between efficiency-adjusted public capital and economic growth. A debate on whether capital grants, and especially EU funds actually contribute to growth has gained prominence lately. This paper empirically assesses the relationship between the quality of public investment, capital grants, and growth in a sample of 43 emerging and peripheral economies over 1991-2015. To this end, the contribution of public capital to growth is estimated using efficiency-adjusted public capital stock series, constructed reflecting the quality of public investment management institutions. In addition, the determinants of effective public investment are analyzed. The results suggest that capital grants contribute positively to effective public investment, and the latter is significant in explaining variations in economic growth. Finally, the paper illustrates the impact of raising EU funds absorption on potential growth in emerging and peripheral EU countries.
\end{abstract}

JEL Classification Numbers: F35, F36, H54, O11, O40

Keywords: public capital stock, effective public investment, capital grants, EU funds, economic growth.

Author's E-Mail Address: ECrivelli@,imf.org

\footnotetext{
${ }^{1}$ I am grateful to Tudor Grosu, Tonny Lybek, Marina Marinkov, Dan Matei, Samah Mazraani, Boaz Nandwa, Marcos Poplawski-Ribeiro, and to seminar participants at the National Bank of Romania and the IMF for many helpful comments and suggestions. Nemanja Jovanovic provided superb assistance with consolidating the data.
} 


\section{CONTENTS}

I. Introduction

II. Efficiency-adjusted public capital and growth

III. Capital grants and public capital accumulation 10

IV. Estimating the impact of EU funds on growth $\underline{13}$

V. Concluding remarks $\underline{14}$

\section{FIGURES}

1. Public capital spending, efficiency, and infrastructure quality

2. Public capital stock

3. EU funds and potential growth

14

\section{TABLES}

1. Efficiency-adjusted public capital and growth, GMM $\underline{9}$

2. Efficiency-adjusted public capital and potential growth, GMM 10

3. Determinants of public capital accumulation

\section{APPENDICES}

I. Data $\underline{15}$

II. Additional results

$\underline{16}$

\section{APPENDIX TABLES}

1. Summary statistics 16

2. Efficiency-adjusted public capital and growth, OLS-FE $1 \frac{16}{17}$

3. Determinants of public capital accumulation, OLS-FE 17 


\section{INTRODUCTION}

The link between infrastructure investment and growth has come to prominence in public debate, prompted in part by the increased awareness of the relatively large efficiency gaps of public capital spending in emerging economies. Figure 1 illustrates this for a sample of emerging and advanced economies. The average efficiency gap among emerging economies has been estimated at about 15 to 20 percent depending on the region, as compared to about 8 percent in advanced European economies (IMF, 2016). In addition, while public capital spending in emerging economies has grown at a much faster pace in recent years, the quality of infrastructure is relatively low.

Figure 1. Public capital spending, efficiency, and infrastructure quality

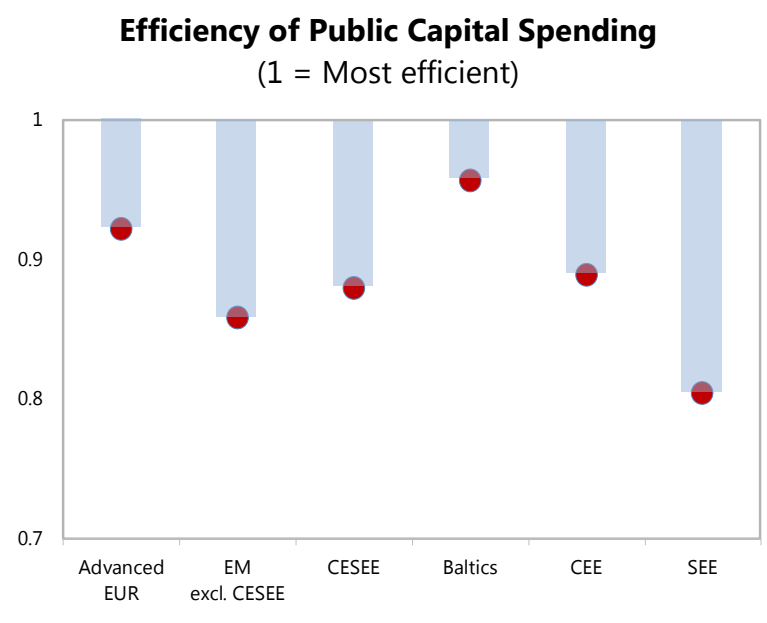

Sources: IMF (2016). For country groups see Appendix I. Note: The efficiency frontier is given by countries achieving the highest quality and access to infrastructure for a given level of public capital stock and income.

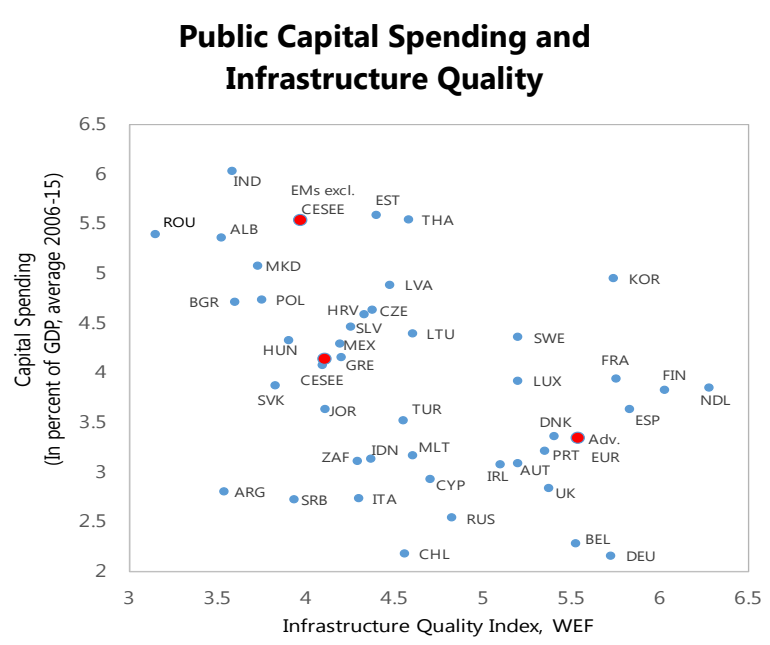

Sources: Eurostat; WEO, and World Economic Forum quality of infrastructure index (2015) on roads, railroads, seaports, and air transport (average).

And reinforced by the findings in recent literature suggesting that the efficiency with which public investment is turned into productive physical capital is key in affecting economic growth. In recent years, studies have empirically analyzed the impact of public capital spending on growth. Several studies use the production function approach, that incorporates the public capital stock as an additional input factor (Romp and De Hann, 2007; Arslanalp and others, 2010). But notwithstanding the wide range of theoretical and empirical frameworks employed, most studies have found a positive impact of public capital on growth. ${ }^{2}$ More recently, however, Pritchett (2000) and Caselli (2005) have argued that the impact of public capital on growth cannot be properly assessed unless the efficiency of public

\footnotetext{
2 Aschauer (1989) was the first to recognize the role of public capital in explaining the fall in productivity observed in the US in the 1970s and 1980s. The literature following his contribution have found a large impact of public capital on growth. For surveys, see Sturm and others (1998); Romp and De Haan (2007); and Bom and Ligthart (2010).
} 
investment is considered. To fill this gap in the literature, Gupta and others (2014) construct efficiency-adjusted public capital stock series - reflecting the quality of public investment management institutions - and find that ignoring public investment inefficiencies leads to an underestimation of the impact of public and private capital on growth in a sample of 52 lowand middle-income countries. ${ }^{3}$

\section{With significant resources made available to finance infrastructure, their actual capacity to generate growth, and the conditions under which this is more likely,} becomes particularly relevant. With large aid flows to developing countries in the form of capital grants, it is crucial to assess the type of incentives they produce, how these funds are allocated, and whether they help raise public investment efficiency, and thereby increase growth. A clear example is given by the growing importance of EU structural and investment funds in recent years. The average annual European Union (EU) funds absorption across the Central, Eastern, and Southeastern European (CESEE) EU members was 1.5 percent of recipient countries' GDP during 2007-15, about a third of government investment in these countries. Several authors have suggested that aid recipient countries may be inclined to divert their use for purposes not intended by the donor (Martins, 2007, Acosta and de Renzio, 2008, Morrisey, 2015), even resulting in a decrease in government capital spending (Combes and others, 2016). EU funds, however, are in principle designed to target infrastructure investment, usually require strong feasibility studies, and aid-recipient countries are subject to ex-ante conditionality (European Commission, 2017). The question is whether increasing the share of EU-funded investment results in higher quality of public investment.

This paper aims to empirically assess the impact of capital grants on economic growth using a two-step estimation approach. First, the link between efficiency-adjusted public capital stock and growth is established, following Gupta and others (2014) by estimating a growth equation that incorporates efficiency-adjusted public capital stock series, constructed reflecting the quality of public investment management institutions. Second, the determinants of efficiency-adjusted public capital accumulation are analyzed, with special focus on the role of capital grants - and particularly EU funds. Finally, the paper shows how these two forces work together, by illustrating the impact of raising EU structural and investment funds on potential growth in CESEE-EU countries. To this end, the paper uses a panel of 43 emerging and peripheral economies over the period 1991-2015. The results suggest that capital grants contribute positively to efficiency-adjusted public capital accumulation, and the latter is significant in explaining variations in economic growth. The estimates suggest that the increase in EU funds implied in full absorption of the 2014-20 budget could lead to about one percentage point higher potential GDP growth among some CESEE-EU countries.

This paper contributes to earlier literature in several ways. First, the public capitalgrowth relationship in Gupta and others (2014) is revisited by extending substantially the

\footnotetext{
${ }^{3}$ Relatedly, IMF $(2014,2015)$ argues that higher spending efficiency, especially in emerging economies can amplify the impact of public investment on growth.
} 
middle-income country coverage, namely by including all the 22 emerging European countries, as well as other peripheral European economies. Second, in addition to analyzing the impact of efficiency-adjusted public capital on real GDP growth, this paper uses estimates of potential real GDP growth that may better capture long-term historical trends, mitigating business-cycle effects. Third, the determinants of public capital accumulation are empirically assessed, following Sturm (2001), but using instead the constructed efficiencyadjusted public capital stock series to focus on the possible impact of capital grants. While research on the determinants of public capital spending has received very little empirical attention per se, and especially in relation to developing countries, ${ }^{4}$ efficiency considerations have not been addressed in the empirical literature. Finally, several papers have looked at the impact of EU funds on growth with rather inconclusive results. ${ }^{5}$ The role of efficiency to fully realize their potential — through productive investment — is, however, widely acknowledge (Marzinotto, 2012). As such, it is striking that no broad empirical assessment of the impact of EU funds on efficient public capital accumulation and thereby on growth has been pursued, especially in relation to emerging and peripheral economies in the EU, by far the largest beneficiaries. ${ }^{6}$ This is the gap in the literature that this paper aims to fill.

The reminder of the paper proceeds as follows. The next section sets out the framework and reports results on the efficiency-adjusted public capital-growth relationship. Section III empirically assess the determinants of efficiency-adjusted public capital accumulation, including the implied impact of capital grants - and specifically EU funds. Section IV illustrates the impact of EU funds on potential growth in developing and peripheral EU countries. Section V concludes. Appendices provide further details on data and report on robustness checks.

\footnotetext{
${ }^{4}$ Earlier papers on the determinants of public investment include De Haan and others (1996) on OECD economies, and Randolph and others (1996), Rajkumar and Swaroop (2008), and Guerguill and others (2014) on low-and middle-income countries; and more recently, Turrini (2004); and Mehrotra and Välilä (2006) on European countries.

${ }^{5}$ A significantly positive impact of EU structural funds on growth was found, for example, in Dall'erba and Gallo (2004), and Puigcerver-Penalver (2004), whereas no significant impact was found in Ederveen and others (2006), and Garcia-Mila and McGuire (2001). See Akbulut (2014) for a recent summary of empirical tests; and Marzinotto (2012) for a review of macroeconomic simulations and empirical tests.

${ }^{6}$ Berg and others (2013), Araujo and others (2016), and Atolia and others (2017), have developed theoretical models on the determinants of public capital spending and the role of its efficiency.
} 


\section{Efficiency-AdJusted Public Capital and Growth}

The contribution of public capital to growth is estimated using a production function approach. Following Gupta and others (2014), a Cobb-Douglas production function technology is specified as:

$$
\ln Y_{i t}=\alpha+\beta_{1} \ln S_{i t}+\beta_{2} \ln K_{i t}+\beta_{3} \ln G_{i t}+\varepsilon_{i t}
$$

Where $Y_{i t}$ is real GDP; and $S_{i t} ; K_{i t}$; and $G_{i t}$ are labor supply, the private capital stock, and the public capital stock, all in logs, respectively. Equation (1) is estimated using ordinary least squares with time and country fixed effects (OLS-FE). In addition, to address concerns regarding possible endogeneity of public capital due to feedback from income-savings decisions on capital accumulation, a Blundell and Bond (1998) system Generalized Method of Moments (GMM) estimator is used. ${ }^{7}$ The paper uses unbalanced panel data for 43 countries (including 36 emerging economies worldwide and peripheral European economies) over the period 1991-2015. Full details of the dataset and summary statistics are presented in the Appendix I.

Capital stocks are constructed using a perpetual inventory equation. Following Gupta et al. (2014), the equation for public capital stock $(G)$ is modified to reflect the efficiency of public investment, taking into account the quality of PIM institutions and government effectiveness in each country:

$$
G_{i t}=G_{i t-1}-\delta_{i t} * G_{i t-1}+q_{i t} * I_{i t-1}
$$

Where for each country $i, G_{i t}$ is the stock of public capital at time $t$, and $I$ is public investment spending at time $t-1, \delta$ is country $i$ 's time-varying rate of depreciation of the capital stock, and $q$ is an index that captures the efficiency of public investment. This index varies between 0 , when all public resources are totally wasted, and 1 , when full efficiency is achieved for government spending. ${ }^{8}$ Two indicators are used as a proxy for $q$. The first one is a normalized index based on the IMF (2015)'s Public Investment Management Assessment (PIMA) tool. ${ }^{9}$ The PIMA framework is similar to several other diagnostic tools, such as the

\footnotetext{
${ }^{7}$ See for example Roodman (2009). System-GMM models use second and longer lags of the potentially endogenous variables (and their differences), making these variables predetermined (i.e. uncorrelated with the error term).

${ }^{8}$ The same methodology, using the perpetual inventory equation, is used to derive private capital stocks $K_{i t}$, assuming $q_{i t}=1$.

${ }^{9}$ PIMA is composed of 15 indicators grouped into four stages of the public investment management cycle: (i) Planning; (ii) Allocation; and (iii) Implementation (IMF, 2015). Countries are scored based on different indicators, which are then combined to construct the overall index. IMF (2015) provides details of the PIMA assessment, covered areas, and indicators. A more recent study (IMF, 2016) extends the coverage to all CESEE countries. The PIMA scores for the added CESEE countries are based on country authorities' and IMF staff assessments.
} 
previous Public Investment Management Index (Dabla-Norris and others, 2011) used in the analysis in Gupta and others (2014), but is more comprehensive as it brings in the macrofiscal dimension of the public investment process such as fiscal rules, central-local coordination, Public Private Partnership management, and regulation of state-owned infrastructure companies. While this indicator is time-invariant, it is likely that structural reforms aimed at improving the efficiency of investment processes take time to implement. Still, to reflect the possibility that investment efficiency may evolve over time, a second, time-variant indicator is used as a proxy for $q$, based on the World Bank's Government Effectiveness Indicator. Countries included in the sample are those for which data on investment and growth are available from the Penn World Table and the IMF's WEO, and a PIMA assessment has been conducted.

Figure 2 shows a large gap between the estimated average efficiency-adjusted and the unadjusted public capital stock series, reflecting the fact that not all public capital spending translates into effective public capital. The estimated series are very similar for both time-variant and time-invariant proxy indicators of public investment efficiency. For the countries in the sample, the gap was about 8 percentage points of GDP in the 1990s, but has widened to about 20 percent more recently. This indicates an overestimation of measures of public capital stock that ignore efficiency considerations. Figure 2 also shows that unlike unadjusted public capital stock - that has remained relatively constant - the efficiencyadjusted public capital stock presents a pronounced downward trend, declining from 58 percent of GDP in 1991 to about 40 percent of GDP in 2015.

Figure 2. Public capital stock

(Percent of GDP, 1991-15)

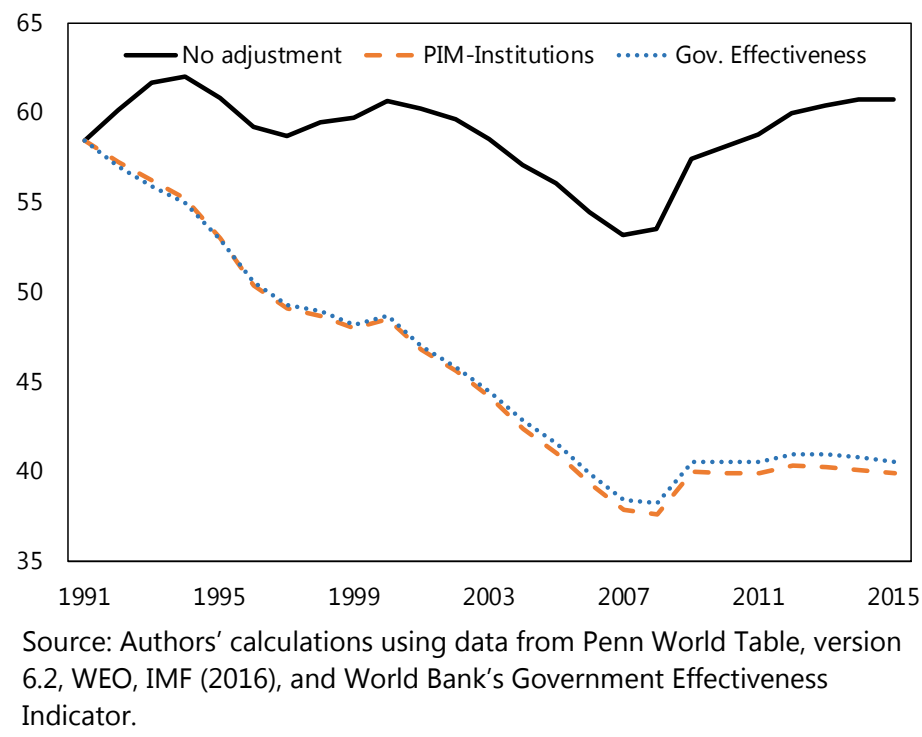




\section{Efficiency-adjusted public capital has a larger impact on growth among middle-income} and peripheral countries. Table 1 presents the results of estimating equation (1) on real GDP growth when using the system-GMM estimator. Column 1 uses the unadjusted public capital stock series, while columns 2-3 present the results using efficiency-adjusted public capital stocks. The focus here is on the comparison of the calculated marginal productivities for unadjusted and efficiency-adjusted public capital stock. ${ }^{10}$ The difference in marginal productivities is noticeable: the MPG increases from 0.46 to 0.61 for PIM-adjusted series. Results are similar when using government effectiveness-adjusted series. Overall, the estimated marginal productivities are comparable with those reported in Gupta and others (2014) for middle-income countries. Comparison of results also suggests that using unadjusted public capital stocks leads to underestimating the contribution of private capital, which is reflected in a lower implied marginal productivity. These results imply that ignoring public investment inefficiencies leads to underestimating the impact of both private and public capital inputs on growth. Finally, for robustness, Appendix II Table A2 presents results using a fixed-effects estimator (OLS-FE), for the full sample and for a sub-sample of only middle-income countries (that is, excluding European peripheral countries). Results are qualitatively similar and comparable to earlier literature.

Table 1. Efficiency-adjusted public capital and growth, GMM

\begin{tabular}{|c|c|c|c|}
\hline & $\begin{array}{c}\text { No adjustment } \\
(1)\end{array}$ & $\begin{array}{c}\text { PIM-Institutions } \\
(2)\end{array}$ & $\begin{array}{c}\text { Gov. Effectiveness } \\
(3)\end{array}$ \\
\hline Labor & $\begin{array}{c}0.449 * * \\
(0.228)\end{array}$ & $\begin{array}{l}0.457 * * \\
(0.225)\end{array}$ & $\begin{array}{c}0.420 * * \\
(0.186)\end{array}$ \\
\hline Private Capital & $\begin{array}{c}0.201 * * * \\
(0.092)\end{array}$ & $\begin{array}{c}0.228 * * * \\
(0.097)\end{array}$ & $\begin{array}{c}0.236^{* *} \\
(0.128)\end{array}$ \\
\hline Public Capital & $\begin{array}{c}0.272 * * \\
(0.159)\end{array}$ & .. & $\ldots$ \\
\hline Eff-Adj. Public Capital & $\ldots$ & $\begin{array}{c}0.280^{* *} \\
(0.130)\end{array}$ & $\begin{array}{c}0.288^{* *} \\
(0.144)\end{array}$ \\
\hline \multicolumn{4}{|c|}{ Implied Marginal Productivities } \\
\hline Private Capital & 0.18 & 0.21 & 0.22 \\
\hline Public Capital & 0.46 & $\ldots$ & $\ldots$ \\
\hline Eff-Adj. Public Capital & $\ldots$ & 0.61 & 0.63 \\
\hline Hansen J-statistic (p-value) & 0.158 & 0.600 & 0.610 \\
\hline Observations & 1065 & 1065 & 1065 \\
\hline Countries & 43 & 43 & 43 \\
\hline
\end{tabular}

\footnotetext{
${ }^{10}$ The marginal product of factors is computed as MPX $=\alpha(\mathrm{Y} / \mathrm{X})$, where $\alpha$ is the common factor share (that is the estimated $\beta 2$ and $\beta 3$ for private and public capital, respectively), $Y$ is GDP and X the stock of private or public capital, respectively.
} 
For robustness, Equation (1) is estimated using IMF's World Economic Outlook (WEO) data on potential real GDP growth. Using potential output in the estimation has two advantages: first, it captures long-term historical trends that can be seen as a partial substitute for longer time series, unavailable for most emerging European economies. Second, it mitigates business-cycle effects that can be present in real GDP series. ${ }^{11}$ The results presented in Table 2 are qualitatively similar as those shown above.

Table 2. Efficiency-adjusted public capital and potential growth, GMM

\begin{tabular}{|c|c|c|c|}
\hline & $\begin{array}{c}\text { No adjustment } \\
(1)\end{array}$ & $\begin{array}{c}\text { PIM-Institutions } \\
(2)\end{array}$ & $\begin{array}{c}\text { Gov. Effectiveness } \\
(3)\end{array}$ \\
\hline Labor & $\begin{array}{l}0.276^{*} \\
(0.152)\end{array}$ & $\begin{array}{c}0.305^{* * *} * \\
(0.125)\end{array}$ & $\begin{array}{c}0.410^{* *} \\
(0.171)\end{array}$ \\
\hline Private Capital & $\begin{array}{l}0.217^{*} \\
(0.164)\end{array}$ & $\begin{array}{c}0.226 * * * \\
(0.060)\end{array}$ & $\begin{array}{c}0.233 * * \\
(0.111)\end{array}$ \\
\hline Public Capital & $\begin{array}{c}0.219^{* *} \\
(0.104)\end{array}$ & $\ldots$ & $\ldots$ \\
\hline Eff-Adj. Public Capital & $\ldots$ & $\begin{array}{c}0.327 * * \\
(0.153)\end{array}$ & $\begin{array}{c}0.270 * * \\
(0.121)\end{array}$ \\
\hline \multicolumn{4}{|c|}{ Implied Marginal Productivities } \\
\hline Private Capital & 0.20 & 0.21 & 0.22 \\
\hline Public Capital & 0.37 & $\ldots$ & $\ldots$ \\
\hline Eff-Adj. Public Capital & $\ldots$ & 0.71 & 0.59 \\
\hline Hansen J-statistic (p-value) & 0.359 & 0.520 & 0.167 \\
\hline Observations & 785 & 785 & 785 \\
\hline Countries & 37 & 37 & 37 \\
\hline
\end{tabular}

\section{Capital Grants and Public Capital accumulation}

Next, the paper considers the determinants of public capital accumulation among the countries in the sample. Following Sturm (2001), the structural and economic determinants of public capital accumulation are explored by estimating equations of the form:

$$
\text { d. } \ln G_{i t}=\alpha+\gamma_{1} \text { Structural }_{i t}+\gamma_{2} \text { Economic }_{i t}+\gamma_{3} \text { Grants }_{i t}+\varepsilon_{i t}
$$

Where $d . \ln G_{i t}$ is the annual change in the public capital stock (in logs), and the determinants are grouped into structural and economic control variables, as well as grants (EU structural

\footnotetext{
${ }^{11}$ Using 5-year averages, instead, as proposed by Gupta and others (2014) is not feasible here because it reduces the sample size significantly.
} 
and investment funds and other capital grants). Table 3 presents the results of estimating Equation (3) using system-GMM to address possible endogeneity (Appendix II Table A3 presents the results using ordinary least squares with time and country fixed effects).

Table 3. Determinants of public capital accumulation

\begin{tabular}{|c|c|c|c|c|}
\hline & $(1)$ & $(2)$ & (3) & (4) \\
\hline & \multicolumn{4}{|c|}{ System-GMM 1/ } \\
\hline & \multicolumn{2}{|c|}{ No adjustment } & $\begin{array}{c}\text { PIM } \\
\text { Institutions }\end{array}$ & $\begin{array}{c}\text { Gov. } \\
\text { Effectiveness }\end{array}$ \\
\hline \multirow[t]{2}{*}{$\Delta$ Public Capital, lagged } & $0.147 *$ & $0.248 * * *$ & $0.366^{* * *}$ & $0.301 * * *$ \\
\hline & $(0.098)$ & $(0.081)$ & $(0.114)$ & $(0.107)$ \\
\hline \multirow[t]{2}{*}{$\Delta \mathrm{GDP}$} & $0.629 * * *$ & $0.456^{* * *}$ & $0.352 * * *$ & $0.233 * * *$ \\
\hline & $(0.136)$ & $(0.105)$ & $(0.073)$ & $(0.085)$ \\
\hline \multirow[t]{2}{*}{ Agriculture } & $0.007^{* *}$ & $0.018 * *$ & 0.007 & $-0.001 *$ \\
\hline & $(0.001)$ & $(0.008)$ & $(0.005)$ & $(0.000)$ \\
\hline \multirow[t]{2}{*}{ Public Debt } & $-0.005 * * *$ & $-0.003 * * *$ & $-0.002 * * *$ & $-0.005^{* * *}$ \\
\hline & $(0.001)$ & $(0.001)$ & $(0.001)$ & $(0.001)$ \\
\hline \multirow[t]{2}{*}{$\Delta$ Private Capital, lagged } & $0.015^{* *}$ & 0.035 & $0.102 * *$ & $0.096 * *$ \\
\hline & $(0.007)$ & $(0.052)$ & $(0.052)$ & $(0.054)$ \\
\hline \multirow[t]{2}{*}{$\Delta$ Primary Balance } & $-0.033 * *$ & & & \\
\hline & $(0.017)$ & & & \\
\hline \multirow[t]{2}{*}{$\Delta$ Capital Grants (Other) } & & $0.398 * *$ & $0.411^{* * *}$ & $0.410 * *$ \\
\hline & & $(0.153)$ & $(0.145)$ & $(0.181)$ \\
\hline \multirow[t]{2}{*}{$\Delta$ EU Grants } & & 0.257 & $0.331 * *$ & $0.363 * *$ \\
\hline & & $(0.198)$ & $(0.176)$ & $(0.190)$ \\
\hline \multirow[t]{2}{*}{ Constant } & $0.004 * *$ & $0.045^{* * *}$ & $0.029 * *$ & $0.057 * * *$ \\
\hline & $(0.001)$ & $(0.012)$ & $(0.010)$ & $(0.013)$ \\
\hline R-squared & 0.769 & $\ldots$ & $\ldots$ & $\ldots$ \\
\hline Hansen J-statistic (p-value) & $\cdots$ & 0.358 & 0.534 & 0.556 \\
\hline Observations & 654 & 654 & 654 & 654 \\
\hline Number of countries & 41 & 41 & 41 & 41 \\
\hline
\end{tabular}

Notes: Dependent variable is log-difference of public capital. Robust errors, in parentheses; ***(****) indicate significance at $1(5,10)$ percent.

1/ One step, robust, system GMM, including time fixed-effects, with instruments based on lagged differences in the logdifference of public capital, debt-to-GDP ratio, and log-difference of grants (collapsed to avoid proliferation in the number of instruments) in levels equation, and lags of their levels in the differenced equation.

Most of the control variables are statistically significant and present the expected sign. The lagged dependent variable captures persistence in public capital accumulation over time. Structural variables proxy the overall development of the economy, reflecting a growing demand for public services, and because of a higher degree of economic and institutional sophistication. To reflect this, the growth rate of real GDP is included, which as expected is 
positively correlated to public capital accumulation. It can also correct for possible cyclical effects, not captured otherwise in other control variables. Following the same argument, the share of agriculture in value-added is included, which as expected is also positively correlated to public capital accumulation, suggesting that rural areas are in relatively more need of public infrastructure investment. ${ }^{12}$ Economic variables include public debt, the primary fiscal balance, and private capital accumulation. A higher level of public debt may lead to restrictive fiscal policy measures, thus negatively affecting public capital accumulation (Roubini and Sachs, 1989). A higher primary balance reflects in lower public capital accumulation, implying that at least part of public investment is deficit financed. ${ }^{13}$ This also reflects the fact that public capital spending is less rigid than current spending on wages and subsidies, thus being more sensitive to fiscal consolidation (De Hann and others, 1996; Mehrotra and Välilä, 2006). Finally, private capital accumulation is positively correlated with public capital accumulation, suggesting the existence of a crowding-in effect (Bom and Ligthart, 2014). ${ }^{14}$

Capital grants and especially EU funds contribute to efficiency-adjusted public capital accumulation. Column 2 looks at the impact of grants on public capital accumulation using the unadjusted series, while Columns 3-4 use the efficiency-adjusted public capital stock series. The growth rate of capital grants is significantly positively correlated with public capital accumulation. In particular, the growth rate of EU structural and investment funds significantly and positively influences efficiency-adjusted public capital accumulation only. The estimated coefficient suggests that a 10 percent increase in EU funds raises efficiencyadjusted public capital by about 4 percent. These results are consistent with earlier findings suggesting that the supportive institutional environment (Marzinotto, 2012) improves targeting of infrastructure investment and thereby increases the growth potential of EU funds. The fact that EU funds are effective at increasing efficiency-adjusted public investment only - with efficiency here reflecting the quality of countries' institutions-is consistent with the findings of earlier literature indicating that the impact of foreign aid on growth in developing countries is significant only in the presence of good policies and institutions (Burnside and Dollar, 2000; Young and Sheehan, 2014). Similarly, the ex-ante conditionality component ${ }^{15}$ may be contributing to the better outcome (European Commission, 2017).

\footnotetext{
${ }^{12}$ Qualitatively identical results were obtained when including population growth as suggested in Randolph and others (1996) and Sturm (2001).

${ }^{13}$ This variable has been dropped in Columns 2-4 due to large collinearity with grants, as the latter is one of the determinants of the former. Inclusion, however, does not qualitatively affect the results on grants.

${ }^{14}$ An assumption of higher productivity of private investment induced by more public capital is used in simulations using the global DGSE-EAGLE model (Gomes and others, 2010) to establish the link between EU funds and output growth.

${ }^{15}$ In a recent paper, Crivelli and Gupta (2017) show that conditionality can help mitigate the negative impact of aid on revenue collection.
} 


\section{ESTIMATING THE IMPACT OF EU FUNDS ON GROWTH}

\section{The approach here provides a simple way to size the impact of capital grants (and} specifically of EU structural and investment funds) on growth. Given that the available budget (the financial allocations) of EU structural and investment funds over the 2014-2020 programing period have been set for each country, the impact of an increase in EU funds absorption on growth can be estimated taking: (i) the estimated impact of EU funds on efficiency-adjusted public capital (the estimated $\gamma_{3}$ from equation (3)), (ii) the impact of the latter on growth (the estimated $\beta_{3}$ from equation (1)), and (iii) the annual average increase in EU funds over the period of analysis. More precisely, the growth impact (in percentage points) in country $i$ over a certain period of time $t$ as a consequence of a higher absorption of EU funds can be estimated as

$$
\Delta \text { Growth }_{i t}=\gamma_{3} * \beta_{3} * \Delta E U \text { Funds }_{i t}
$$

The impact of EU funds on potential growth can be substantial. By way of illustration, Figure 3 below shows how an increase in EU funds absorption in the current 2014-2020 programing period can impact potential real GDP growth among the emerging and peripheral EU countries in the sample. The starting point is the actual absorption of EU funds, and the average potential real GDP growth during the previous 2007-2013 programing period. ${ }^{16}$ The increase in EU funds absorption over the two programing periods would imply an average increase in potential growth from about 0.2 percentage points among peripheral EU countries and 0.3 percentage points among Baltic countries, to about 1 percentage point among Southeastern-EU countries (SEE-EU). For the largest recipients of EU funds in CEE and SEE-EU countries, the increase in EU funds over the two programming periods is about 2 percentage points of the estimated average potential GDP, implying an estimated multiplier of EU funds on growth of about 0.5. These estimates are in line with recent estimates on the impact of EU funds on growth, as well as, more broadly, estimates of capital spending multipliers. IMF (2017) estimates the multiplier impact of the change in EU funds on real GDP growth between 0.5 and 0.7 percentage points. Spilimbergo and others (2009) estimate capital spending multipliers to be between 0.5 and 1.8 depending on country circumstances. ${ }^{17}$

\footnotetext{
${ }^{16}$ Estimated using $\gamma_{3}=0.3$ and $\beta_{3}=0.6$.

${ }^{17}$ In addition, Kilponen and others (2015), Paliova and Lybek (2014), Muir and Weber (2013), and Klyuev and Snudden (2011) provide country-specific estimates for emerging European countries that are also in line with the estimates in this paper.
} 
Figure 3. EU funds and potential growth (Percent)

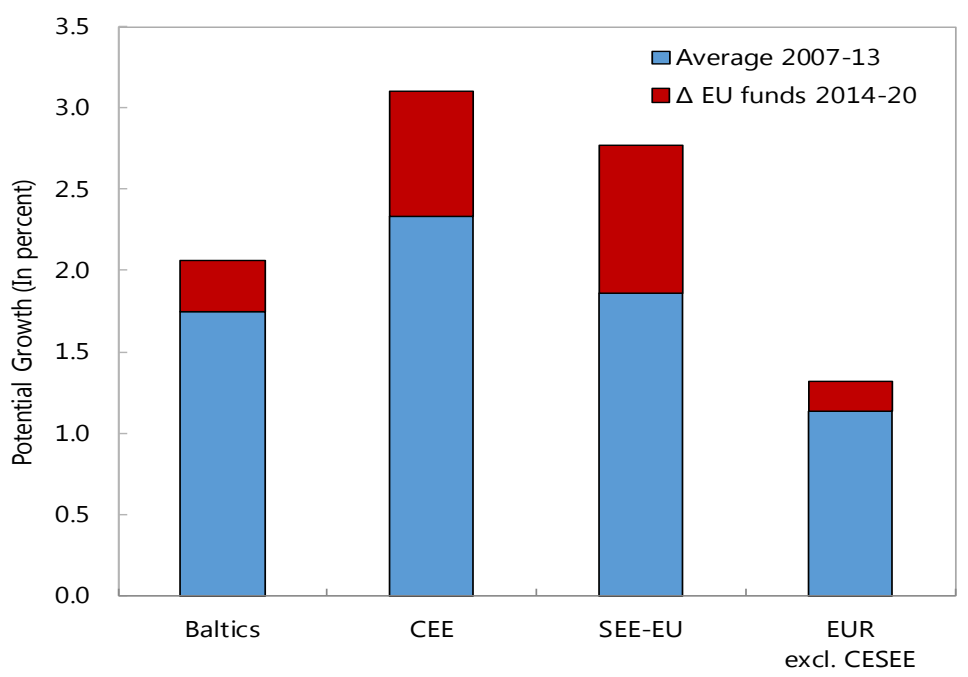

Source: Authors' calculations using data from WEO and Eurostat. Note: The impact of EU grants on potential growth by sub-regions is a weighted average based on the share of EU grants on potential output in 2015.

\section{CONCLUding Remarks}

There has been a long-standing debate about the desirability of raising public spending efficiency to improve growth outcomes. And recent empirical findings for low- and middle-income countries have confirmed that public investment efficiency is key to properly assess the impact of both public and private capital on growth. The issue itself, of course, is not new. What is new is the attention is receiving from policy makers, in part, due to the sharp increase in available resources to emerging economies to finance public infrastructure. And the interest, by donor countries and multilateral institutions, in ensuring that these resources are properly channeled.

The central question posed at the outset was, therefore, whether capital grants contribute to building efficiency-adjusted public capital that is supportive of growth in emerging economies. The empirical analysis in this paper suggests that they do, with signs that their impact is leveraged by the quality of institutions - especially public investment management institutions - in recipient countries and the conditions under which aid is provided. The EU structural and investment funds, requiring an institutional upgrade and subject to ex-ante conditionality to ensure disbursement, serve as good example. Indeed the paper shows that the increase in EU funds implied in the current 2014-20 program budget could lead to up to one percentage point higher potential GDP growth — about 30 to 50 percent higher than currently projected — among CESEE-EU countries.

Altogether the findings in this paper suggest that policy makers and donors need to pay particular attention to strengthening institutions. And this highlights the importance of 
bilateral donors and international agencies in providing technical assistance to help recipient countries strengthen public investment management institutions to ensure that public capital spending translates into high quality infrastructure. While beyond the scope of the paper, the experience in emerging countries (IMF, 2015, 2016) suggests that project appraisal, selection, and transparency of execution could be further improved by: (1) conducting strong feasibility assessments, especially for large infrastructure projects, (2) integrating project prioritization in the budget process, while ensuring a stable source of funding for strategic projects over the medium-term, and (3) undertaking an open and transparent procurement process and publishing results for major projects.

\section{Appendix I: Data}

Countries in the sample. Emerging CESEE: (i) CEE: Czech Rep., Hungary, Slovak Rep., Slovenia, Poland; (ii) SEE: Albania, Bosnia and Herzegovina, Bulgaria, Croatia, Kosovo, FYR Macedonia, Montenegro, Romania, Serbia; (iii) Baltics: Estonia, Latvia, Lithuania; (iv) CIS: Belarus, Russia, Moldova, Ukraine; (v) Turkey. Other Emerging: Argentina, Bolivia, Brazil, Cameroon, Chile, China, India, Indonesia, Jordan, Korea, Mexico, Mozambique, South Africa, Thailand. Other peripheral European countries: Cyprus, Greece, Ireland, Italy, Malta, Portugal, and Spain.

Data on unadjusted private and public capital stocks are taken from the IMF's Investment and Capital Stock Dataset (ICSD), constructed using a perpetual inventory equation (IMF, 2015, Appendix I) using data from the OECD Analytical Database (August 2014), Penn World Table (Version 8.0), and IMF's World Economic Outlook (WEO). Data on labor force, real GDP (PPP, 2011), the share of agriculture in GDP, and the World Bank indicator on government effectiveness are taken from the World Bank's World Development Indicators. Data on potential real GDP, general government's primary balance, and public debt are taken from the IMF's WEO, and International Financial Statistics (IFS). Data on capital grants are taken from Eurostat and the IMF's WEO. Data on EU structural and investment funds are taken from the European Commission's Directorate General for Regional and Urban Policy, available online at:

https://data.europa.eu/euodp/en/data/dataset/funds-absorption-rate 


\section{Appendix Table A1. Summary statistics}

\begin{tabular}{lrrrrr}
\hline & Obs. & \multicolumn{1}{c}{ Mean } & Std. Dev. & \multicolumn{2}{c}{ Min } \\
\hline Public Capital Stock, in logs & 1065 & 29.72 & 2.02 & 25.64 & 32.52 \\
Eff-Adj. Public Capital Stock - PIMA, in logs & 1065 & 29.45 & 2.04 & 25.62 & 34.64 \\
Eff-Adj. Public Capital Stock - Gov. Eff., in logs & 1065 & 29.44 & 2.08 & 25.62 & 35.03 \\
Private Capital Stock, in logs & 1066 & 31.21 & 1.88 & 27.08 & 35.73 \\
Labor Force, in logs & 1075 & 15.62 & 1.82 & 11.86 & 20.51 \\
Real GDP, PPP, 2011, in logs & 1071 & 25.76 & 1.86 & 22.32 & 30.54 \\
Potential real GDP growth, in percent & 853 & 7.23 & 3.06 & 1.74 & 16.01 \\
Agriculture value-added, in percent of GDP & 968 & 9.49 & 8.19 & 0.64 & 55.81 \\
Fiscal Primary Balance, in percent of GDP & 839 & -0.52 & 3.48 & -13.25 & 28.21 \\
Public Debt, in percent of GDP & 927 & 49.08 & 33.72 & 0.00 & 289.55 \\
EU structural and investment funds, in logs & 1075 & 1.62 & 2.86 & 0.00 & 9.36 \\
Capital grants, other, in logs & 771 & 4.12 & 3.19 & 0.00 & 10.91 \\
\hline
\end{tabular}

\section{Appendix II: Additional results}

Appendix Table A2. Efficiency-adjusted public capital and growth, OLS-FE

\begin{tabular}{|c|c|c|c|c|c|c|}
\hline & \multicolumn{2}{|c|}{ No adjustment } & \multicolumn{2}{|c|}{ PIM-Institutions } & \multicolumn{2}{|c|}{ Gov. Effectiveness } \\
\hline & $\begin{array}{l}\text { ALL } \\
(1)\end{array}$ & $\begin{array}{c}\text { MICs } \\
(2)\end{array}$ & $\begin{array}{l}\text { ALL } \\
\text { (3) }\end{array}$ & $\begin{array}{c}\text { MICs } \\
\text { (4) }\end{array}$ & $\begin{array}{l}\text { ALL } \\
(5)\end{array}$ & $\begin{array}{c}\text { MICs } \\
(6)\end{array}$ \\
\hline Labor & $\begin{array}{c}0.369 * * * \\
(0.054)\end{array}$ & $\begin{array}{c}0.407 * * * \\
(0.061)\end{array}$ & $\begin{array}{c}0.395 * * * \\
(0.052)\end{array}$ & $\begin{array}{c}0.450 * * * \\
(0.057)\end{array}$ & $\begin{array}{c}0.439 * * * \\
(0.047)\end{array}$ & $\begin{array}{c}0.477 * * * \\
(0.055)\end{array}$ \\
\hline Private Capital & $\begin{array}{c}0.166^{* * *} \\
(0.057)\end{array}$ & $\begin{array}{c}0.160 * * * \\
(0.068)\end{array}$ & $\begin{array}{c}0.207 * * * \\
(0.067)\end{array}$ & $\begin{array}{c}0.211^{* * *} * \\
(0.070)\end{array}$ & $\begin{array}{c}0.246^{* * *} \\
(0.079)\end{array}$ & $\begin{array}{c}0.237 * * * \\
(0.083)\end{array}$ \\
\hline Public Capital & $\begin{array}{c}0.335 * * * \\
(0.073)\end{array}$ & $\begin{array}{c}0.306^{* * *} * \\
(0.078)\end{array}$ & $\ldots$ & $\ldots$ & $\ldots$ & $\ldots$ \\
\hline Eff-Adj. Public Capital & $\ldots$ & $\ldots$ & $\begin{array}{c}0.307 * * * \\
(0.068)\end{array}$ & $\begin{array}{c}0.251 * * \\
(0.102)\end{array}$ & $\begin{array}{c}0.243 * * * \\
(0.068)\end{array}$ & $\begin{array}{c}0.235^{* * * *} \\
(0.067)\end{array}$ \\
\hline
\end{tabular}

\section{Implied Marginal Productivities}

$\begin{array}{lcccccc}\text { Private Capital } & 0.14 & 0.13 & 0.17 & 0.17 & 0.20 & 0.19 \\ \text { Public Capital } & 0.49 & 0.47 & \ldots & \ldots & \ldots & \ldots \\ \text { Eff-Adj. Public Capital } & \ldots & \ldots & 0.67 & 0.55 & 0.53 & 0.51 \\ & & & & & & \\ \text { squared } & 0.851 & 0.867 & 0.835 & 0.847 & 0.818 & 0.837 \\ \text { servations } & 1065 & 890 & 1065 & 890 & 1065 & 890 \\ \text { untries } & 43 & 36 & 43 & 36 & 43 & 36\end{array}$

Note: Dependent variable is the log of real GDP in international dollars. Ordinary least squares with country fixed effects (OLS-FE). Time fixed effects included in all regressions. Robust errors in parentheses; $* * *(* *, *)$ indicate significance at $1(5,10)$ percent. 


\section{Appendix Table A3. Determinants of public capital accumulation, OLS-FE}

\begin{tabular}{|c|c|c|c|c|}
\hline & $(1)$ & (2) & (3) & (4) \\
\hline & \multicolumn{4}{|c|}{ OLS-FE } \\
\hline & \multicolumn{2}{|c|}{ No adjustment } & $\begin{array}{c}\text { PIM } \\
\text { Institutions }\end{array}$ & $\begin{array}{c}\text { Gov. } \\
\text { Effectiveness }\end{array}$ \\
\hline \multirow[t]{2}{*}{$\Delta$ Public Capital, lagged } & $0.566 * * *$ & $0.575^{* * *}$ & $0.574 * * *$ & $0.586 * * *$ \\
\hline & $(0.055)$ & $(0.063)$ & $(0.073)$ & $(0.074)$ \\
\hline \multirow[t]{2}{*}{$\Delta \mathrm{GDP}$} & $0.140 * * *$ & $0.132 * * *$ & $0.106^{* * *}$ & $0.105^{* * *}$ \\
\hline & $(0.024)$ & $(0.022)$ & $(0.022)$ & $(0.021)$ \\
\hline \multirow[t]{2}{*}{ Agriculture } & $0.004^{* *}$ & $0.005^{*}$ & $0.001 *$ & $0.001 *$ \\
\hline & $(0.002)$ & $(0.004)$ & $(0.000)$ & $(0.000)$ \\
\hline \multirow[t]{2}{*}{ Public Debt } & $-0.001 * *$ & $-0.001 * * *$ & $-0.001 * * *$ & $-0.001 * * *$ \\
\hline & $(0.000)$ & $(0.000)$ & $(0.000)$ & $(0.000)$ \\
\hline \multirow[t]{2}{*}{$\Delta$ Private Capital, lagged } & $0.018^{* *}$ & $0.015^{* *}$ & $0.021^{*}$ & $0.019^{*}$ \\
\hline & $(0.009)$ & $(0.009)$ & $(0.015)$ & $(0.010)$ \\
\hline \multirow[t]{2}{*}{$\Delta$ Primary Balance } & -0.001 & & & \\
\hline & $(0.001)$ & & & \\
\hline \multirow[t]{2}{*}{$\Delta$ Capital Grants (Other) } & & $0.337 * *$ & $0.299^{* *}$ & $0.321 * *$ \\
\hline & & $(0.133)$ & $(0.127)$ & $(0.129)$ \\
\hline \multirow[t]{2}{*}{$\Delta$ EU Grants } & & 0.249 & $0.237^{* *}$ & $0.311^{* *}$ \\
\hline & & $(0.150)$ & $(0.136)$ & $(0.138)$ \\
\hline \multirow[t]{2}{*}{ Constant } & $0.022 * * *$ & $0.030 * * *$ & $0.021^{* *}$ & $0.025 * * *$ \\
\hline & $(0.006)$ & $(0.008)$ & $(0.005)$ & $(0.006)$ \\
\hline R-squared & 0.519 & 0.578 & 0.558 & 0.562 \\
\hline Observations & 731 & 654 & 654 & 654 \\
\hline Number of countries & 42 & 41 & 41 & 41 \\
\hline
\end{tabular}

Notes: Dependent variable is log-difference of public capital. Ordinary least squares with country fixed effects (OLS-FE). Time fixed effects included in all regressions. Robust errors, in parentheses; $* * *(* * *)$ indicate significance at $1(5,10)$ percent. 


\section{References}

Acosta, M, and P. de Renzio, 2008. Aid, rents, and the politics of the budget process. IDS Working Paper 311, Institute of Development Studies, Brighton, United Kingdom.

Akbulut, H., 2014. Testing growth effects of European Union structural funds according to size of government: A dynamic approach. Journal of Business, Economics and Finance 3 (1), p. 50-59.

Araujo, J., B. Li, M. Poplawski-Ribeiro, and L. Zanna, 2016. Current account norm in natural resource rich and capital scarse economies. Journal of Development Economics 120, p. 144156.

Arslanalp, S., F. Bonhorst, S. Gupta, and E. Sze, 2010. Public capital and growth. IMF Working Paper 10/175. International Monetary Fund. Washington, DC.

Aschauer, D., 1989. Is public expenditure productive? Journal of Monetary Economics 23, p. 177-200.

Atolia, M., B. Li, R. Marto, and G. Melina, 2017. Investing in public infrastructure: Roads or schools? IMF Working Paper 17/105, International Monetary Fund. Washington, DC.

Berg, A., R. Portillo, S. Yang, and L. Zanna, 2013. Government investment in resource abundant developing countries. IMF Economic Review 61, p. 92-129.

Blundell, R., and S. Bond, 1998. Initial conditions and moment restrictions in dynamic panel data models. Journal of Econometrics 87, p. 321-40.

Bom, P., and J. Ligthart, 2014. What have we learned from three decades of research on the productivity of public capital? Journal of Economic Surveys, 28 (5), p. 889-916.

Burnside, C., and D. Dollar, 2000. Aid, policies, and growth. American Economic Review 90 (4), p. 847-68.

Caselli, F., 2005. Accounting for cross-country income differences. In: Handbook of economic growth, chapter 5, p. 679-741.

Combes, J., R. Ouedraogo, and S. Tapsoba, 2016. What does aid do to fiscal policy? New evidence. IMF Working Paper 16/112, June, International Monetary Fund. Washington, DC.

Crivelli, E., and S. Gupta, 2017. Does conditionality mitigate the potential negative effect of aid on revenues? Journal of Development Studies 53 (7), p. 1057-74.

Dabla-Norris, E., J. Brumby, A. Kyobe, Z. Mills, and C. Papageorgiou, 2011. Investing in public investment: An index of public investment efficiency. Journal of Economic Growth 17, p. 235-266. 
Dall'erba, S. and J. Gallo, 2004. Regional convergence and the impact of European structural funds 1989-1999: A spatial econometric analysis. Papers in Regional Science 82 (2), p. 21944.

De Hann, J., J. E. Sturm, and B. Sikken, 1996. Government capital formation: explaining the decline. Weltwirtschaftliches Archiv 132 (1), p. 55-74.

Ederveen, S., H. Groot, and R. Nahuis, 2006. Fertile soil for structural funds? A panel data analysis of the conditional effectiveness of European cohesion policy. Kyklos 59 (1), p. 1742.

European Commission, 2017. The value added of ex ante conditionalities in the European structural and investment funds. Staff Working Document 127, March.

Garcia-Mila, T. and T. McGuire, 2001. Do interregional transfers improve the economic performance of poor regions? The case of Spain. International Tax and Public Finance 8 (3), p. 281-95.

Gomes, S., P. Jacquinot, and M. Pisani, 2010. The EAGLE: A model for policy analysis of macroeconomic interdependence in the Euro Area. ECB Working Paper 1195, May, European Central Bank, Frankfurt.

Guerguil, M., M. Poplawski-Riveiro, and A. Shabunina, 2014. Fiscal policy response during the crisis in low-income African economies. In: Post-Crisis Fiscal Policy, ed. By C.

Cottarelli, P. Gerson, and A. Senhadji, Chapter III.11, p. 287-314. Cambridge, MA: MIT

Press, July.

Gupta, S., A. Kangur, C. Papageorgiou, and A. Wane, 2014. Efficiency-Adjusted Public Capital and Growth. World Development, Vol. 57, p. 164-78.

International Monetary Fund, 2014. Legacies, Clouds, Uncertainties. World Economic Outlook, October, Chapter 3. Available at:

http://www.imf.org/en/Publications/WEO/Issues/2016/12/31/ Legacies-Clouds-Uncertainties

International Monetary Fund, 2015. Making Public Investment More Efficient. IMF Policy paper, June. Available at: http://www.imf.org/external/np/pp/eng/2015/061115.pdf

International Monetary Fund, 2016. Efficient Government for Stronger Growth. Regional Economic Issues Report on Central, Eastern, and Southeastern Europe, European Department, November. Available at:

https://www.imf.org/en/Publications/REO/EU/Issues/2017/01/07/ Central-Eastern-and$\underline{\text { Southeastern-Europe1 }}$

International Monetary Fund, 2017. A Broadening Recovery. Regional Economic Issues Report on Central, Eastern, and Southeastern Europe, European Department, November. 
Available at: http://www.imf.org/en/Publications/REO/EU/Issues/2017/05/10/a-broadeningrecovery

Kilponen, J., M. Pisani, S. Schmidt, V. Corbo, T. Hledik, J. Hollmayr, and S. Hurtado, 2015. Comparing fiscal multipliers across models and countries in Europe. ECB Working Paper 1760, March, European Central Bank, Frankfurt.

Klyuev, V., and S. Snudden, 2011. Effects of fiscal consolidation in the Czech Republic. IMF Working Paper 11/65, International Monetary Fund, Washington, DC.

Martins, P., 2007. The impact of foreign aid on government spending, revenue and domestic borrowing in Ethiopia. International Poverty Centre working paper, Brasilia.

Marzinotto, B., 2012. The growth effects of EU cohesion policy: A meta-analysis. Bruegel Working Paper 2012/14, October, Brussels.

Mehrotra, A., and T. Välilä, 2006. Public investment in Europe: Evolution and determinants in perspective. Fiscal Studies 27 (4), p. 443-71.

Morrissey, O., 2015. Aid and fiscal Behavior: Assessing Recent Evidence. World Development 69, pp. 98-105.

Muir, D., and A. Weber, 2013. Fiscal multipliers in Bulgaria: Low but still relevant. IMF Working Paper 13/49, International Monetary Fund, Washington, DC.

Paliova, I., and T. Lybek, 2014. Bulgaria's EU Funds Absorption: Maximizing the Potential! IMF Working Paper 14/21, International Monetary Fund, Washington, DC.

Pritchett, L., 2000. The tyrany of concepts: CUDIE (Cumulated, Depreciated, Investment Effort) is not capital. Journal of Economic Growth, 5, p.361-384.

Puigcerver-Penalver, M., 2004. The impact of structural funds policy on European regions growth: A theoretical and empirical approach. European Journal of Comparative Economics 4 (2), p. 179-208.

Rajkumar, A. and V. Swaroop, 2008. Public spending and outcomes: Does governance matter? Journal of Development Economics 86, p. 96-111.

Randolph, S., Z. Bogetic, and D. Hefley, 1996. Determinants of public expenditure on infrastructure. Transport and communication. World Bank Policy Research Working Paper 1661, The World Bank, Washington, DC.

Romp, W., and J. De Hann, 2007. Public capital and economic growth: A critical survey. Perspektiven der Wirtschaftspolitik, 8, p. 1-140. 
Roodman, D., 2009. How to do xtabond2: An introduction to difference and system GMM in Stata. The Stata Journal, 9, p. 86-136.

Roubini, N., and J. Sachs, 1989. Government spending and budget deficits in the industrial countries. Economic Policy 8, p. 99-132.

Spilimbergo, A., S. Symansky, and M. Schindler, 2009. Fiscal Multipliers. IMF Staff Position Note 09/11, International Monetary Fund, Washington, DC.

Sturm, J-E, G. Kuper, and J. De Hann, 1998. Modeling government investment and economic growth on a macro level: A review. In: Market behavior and macroeconomic modeling. London: MacMillan Press Ltd.

Sturm, J-E., 2001. Determinants of public capital spending in less-developed countries. Working Paper, University of Groningen.

Turrini, 2004. Public investment and the EU fiscal framework. EC Economic Papers 202, May, European Commission Directorate-General for Economic and Financial Affairs, Brussels.

Young, A. and K. Sheehan, 2014. Foreign aid, institutional quality, and growth. European Journal of Political Economy 36, p. 195-208. 